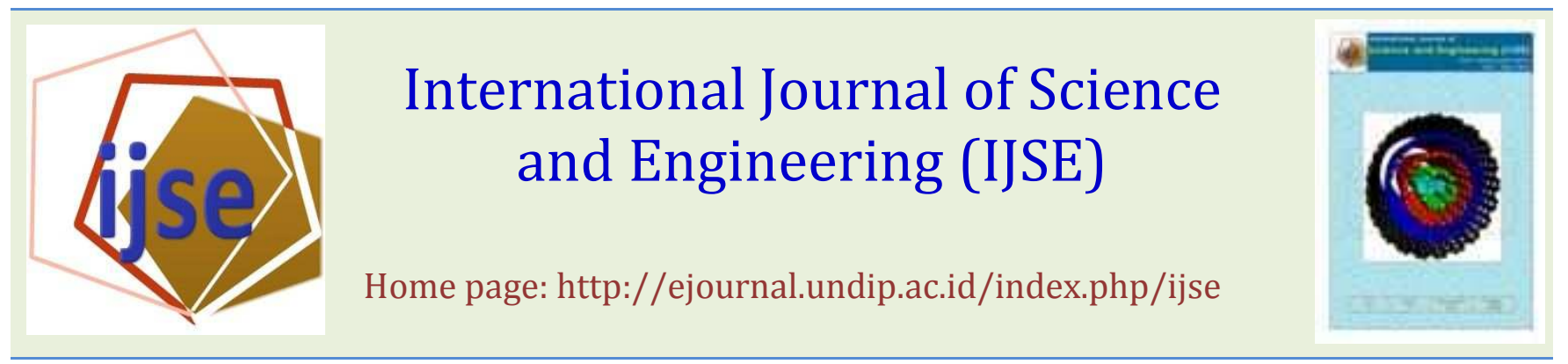

\title{
Analysis of Causality Relationship of Components of Socio- ecological and Socio-economical System for Management of the Outermost Small Islands: A Case of Lingayan Island, Central Sulawesi
}

\author{
Mohammad Saleh Lubis ${ }^{*}$, Azis Nur Bambang ${ }^{2}$, Sahala Hutabarat ${ }^{2}$, Slamet Budi Prayitno ${ }^{2}$ \\ ${ }^{1}$ Marine and Fisheries Agency of Central Sulawesi, Palu 94113, Indonesia \\ Telp. 0451-429379, Fax: 0451-421560 \\ ${ }^{2}$ Deparment of Fisheries, Faculty of Fisheries and Marine Science, \\ Diponegoro University, Semarang 50275, Central Java, Indonesia \\ Email: salehlubis74@gmail.com
}

\begin{abstract}
Indonesia has more than 17,506 islands and 92 islands of them are outermost small islands. Lingayan is one of them located in Northwest of Sulawesi Island and it has geostrategic role to determine the sea boundaries of Indonesian State (NKRI) including the territorial seas, the exclusive economic zone and the continental shelf. Recently, the coastal ecosystems of Lingayan has degraded and the island's economy is weak so they cannot support the life's survival of inhabiting people. This condition could weaken the geostrategic role in accordance with article 121 Chapter VIII of the United Nations Convention on the Law of the Sea (UNCLOS). Based on the above reasons, the study aim to examine and assess the causal relation of components in the socioecological and socio-economical systems as a basis for management of the Lingayan Island with target on conservation of coastal ecosystems and growth of inhabitant' business economic. Causalities relations within components were built using Statistic Equation Model (SEM) with AMOS method and 40 constructed indicators as well as determinate the suitability program using Analytical Hierarchy Process (AHP). The research showed that there is relationship between the components of socio-ecological systems as indicated by the fit model of causal relation path diagram that provides chi square value $=236.994, \mathrm{RMSEA}=0.083, \mathrm{GFI}=$ 0.884. Furthermore, there is relationship between the components of socio-economical that provides chi square value $=192.824$, RMSEA $=0.081, \mathrm{GFI}=0.900$. The most appropriate programs are seaweed cultivation $(34.0 \%)$ and restoration $(23.4 \%)$.
\end{abstract}

Keywords - Lingayan Island; socio-ecological system; socio-economical system

Submission: February 2, $2014 \quad$ Corrected : June 30, 2014

Accepted: Juny 30, 2014

Doi: 10.12777 /ijse.7.1.52-60

[How to cite this article: Lubis, M.S., Bambang, A.N., Hutabarat, S., Prayitno, S.B. . 2014. Analysis of Causality Relationship of Components of Socioecological and Socio-economical System for Management of the Outermost Small Islands: A Case of Lingayan Island, Central Sulawesi. Internat. J. Sci. Eng, 7(1):52-60; Doi: 10.12777/ijse.7.1.52-60]

\section{Introduction}

Administratively, the Lingayan island belongs to the Ogotua Village, North Dampal Sub-District, Toli-Toli District, Central Sulawesi Province and geographically is located on the coordinates of $00^{0} 59^{\prime} 55^{\prime \prime} \mathrm{LU}$ and $120^{0} 12^{\prime} 50^{\prime \prime}$ BT with the land cover of \pm 140.40 Ha and the coastal line of 7,075 Km (Figure 1). This position puts the Island as one of the Indonesia's outermost small islands that directly adjacent to the Malaysian waters. Lingayan has 356 residents or 89 families coming from the tribes of Bugis, Mandar, and Dondo; which mostly have profession as traditional fishermen with subsistence living pattern.

The encountered problem on the island is coastal resource destruction due to improper utilization by the residents. They do it because the level of educational, knowledge and understanding of resources benefits are low. Another problem found is unsustainable economic enterprises run by the residents because there is no support on infrastructures, accessibility to the resources, and low venture capital. These conditions make the residents left the island that led to uninhabited island.

These problems would threatening wider coastal resources destruction and the ecosystems cannot support the resident's life in accordance with Article 121 Part VIII on the Regime of Islands on the United Nations Convention on the Law of the Sea (UNCLOS) in 1982 which was ratified by the Indonesian law No. 17 1985, mention that "Rocks or islands which cannot support human habitation or sole economic life, that have no 
exclusive economic zone or continental shelf, and only entitled to have territorial sea". Therefore, the existing problems in the Island could lead to the strategic roles be useless and could eliminate the Indonesian sea authority in Exclusive Economic Zone and Continental Shelf.

Solving these problems it was done with the approach socio-ecology system and a system of socioeconomical that views that social factors involved in the process of coastal conservation ecosystem by utilizing the consciousness of human about the purpose of ecosystem (Seixas, 2002 and Peloquin, 2007). The concept of linked social ecological systems emerged in an effort to make linkages between the human and ecological components more explicit, as well as focusing on feedback mechanisms by which the two are coupled (Folke et al., 2005). Identifying these links enables us to track the feedbacks between social and ecological systems and is essential for sustainable adaptive resource management (Crona, 2006). Definition of a social ecological system can be considered as a system composed of organized assemblages of humans and non human life form in a spatially determined geophysical setting. The humans are the people living on the island, organized as a family and non humans life forms are populations of plants and animals as coastal resources, and others which are naturalized or native to the area (Halliday and Glaser, 2011).

In addition, socio-economical approached is done since the economic neo classic approached is not sufficient to solve the economic problems and socioeconomical mechanisms would prevent the optimum utilization of ecosystem services (Scheffer, et. al., 2000; Damsar, 2002). Hence need to use broader perspectives in which one of them includes the use of sociology.

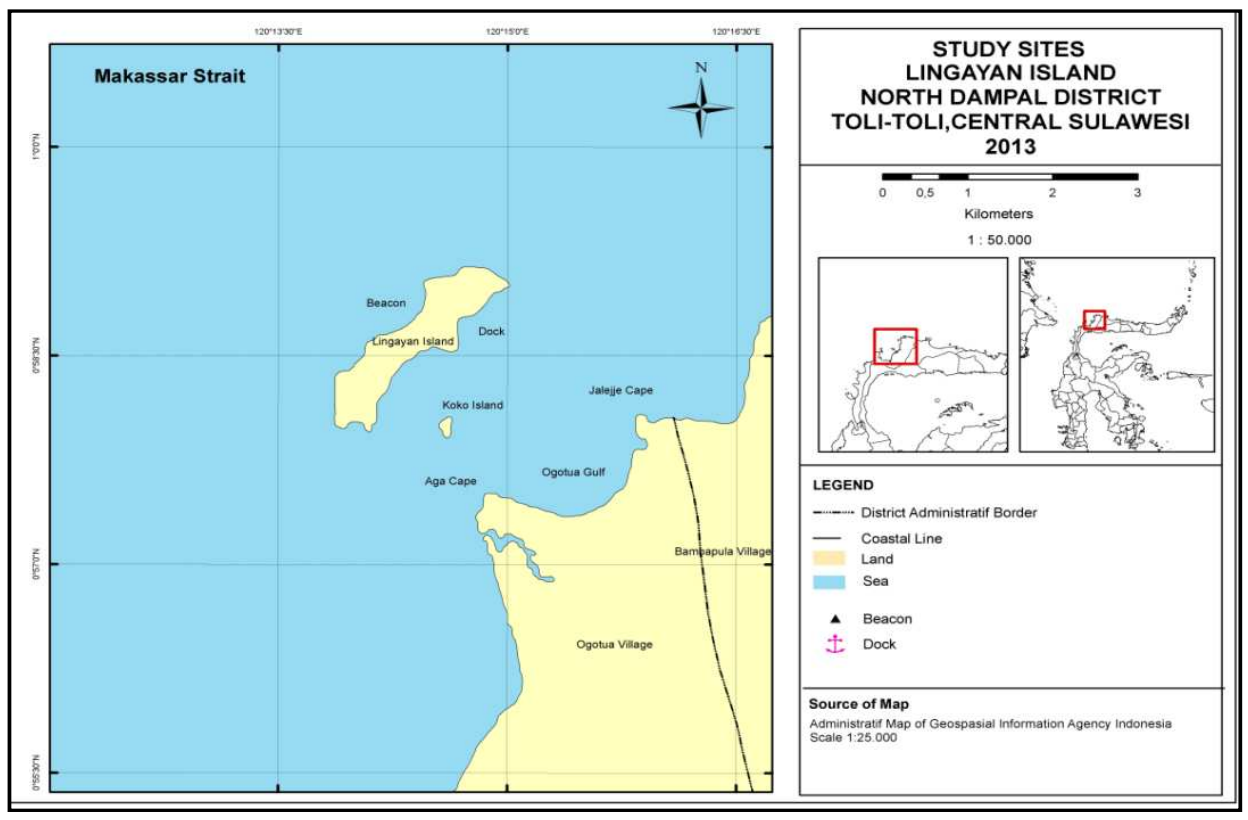

Figure 1. Lingayan Island part of North Dampal Sub-District, Tolitoli District, Central Sulawesi Province.

\section{Materials and Methods}

The study was conducted using descriptive qualitative and quantitative method with a field research and ground survey. Primary data were obtained by distributing questionnaires, in-depth interview and focus group discussion. The objects of study were residents who inhabited the Island, the residents who have activities around the Island, public figures, religious figures, the government of the villages, sub-villages, subdistrict and district, and the officials of relevant institutions. While secondary data were obtained from the relevant government institutions such as Regional Development Planning Agency, the Marine and Fishery Agency, Central Bureau of Statistics, the Office of North Dampal Sub-District, and the Office of Ogotua Village.

Sampling was conducted based on consideration (purposive sampling) which then randomized to be taken as representative of the population with assumption that the community group be examined to give the whole population description. The samples determined for each groups of social ecological and social economical as many as 250 based on the respondents' profession. The components in socio-ecological system consist of education, life norms, knowledge, and view on coastal resources, and conservation. Furthermore, the components in socio-economical system consist of island infrastructures, fish resources accessibility, capital, and diversification of economic enterprise, and island economic growth.

Qualitative data analysis is done by checking the data and tabulations in the form of tables, charts and figures that are available then do explanation and interpretation. Quantitative analysis using the static model (SEM) with AMOS method (Ghozali, 2011). Structural equation of path diagram model is expressed as follow:

A. Socio-ecological System :

$$
\eta 1=\gamma 1.1 \xi 1+\zeta 1
$$


$\eta 2=\gamma 1.2 \xi 1+\gamma 2.1 \xi 2+\zeta 2$

$\eta 3=\gamma 2.2 \xi 2+\beta 1.1 \eta 1+\beta 2.1 \eta 2+\zeta 3$

B. Socio-economical System :

$\eta 4=\gamma 3.1 \xi 3+\gamma 4.1 \xi 4+\zeta 4$

$\eta 5=\gamma 3.2 \xi 3+\gamma 4.2 \xi 4+\beta 4.1 \eta 4+\zeta 5$

$\eta 6=\gamma 3.3 \xi 3+\gamma 4.3 \xi 4+\beta 5.1 \eta 5+\zeta 6$

Symbol: $\xi=$ exogenous variable; $\eta=$ endogenous variable; $\gamma=$ regression coefficient between exogenous and endogenous variable; $\beta=$ regression coefficient between endogenous variable and endogenous variable other; $\zeta=$ error or regression residual value

Suitability test and statistical test conducted by looking at several parameters for assess to overall model fit with recommendations shown in Table 1 and estimation of standardized coefficient parameter $\geq 0.05$. Value and weight of suitability programs using a numerical scale as in Table 2.

Table 1. Goodness Of-Fit Indices*

\begin{tabular}{ll}
\multicolumn{1}{c}{$\begin{array}{c}\text { Goodness of Fit } \\
\text { Index }\end{array}$} & \multicolumn{1}{c}{ Cut of Value } \\
\hline$\chi^{2}$-Chi Square & $\begin{array}{l}\text { Expected minimal } \\
\text { value }\end{array}$ \\
\hline $\begin{array}{l}\text { Significance } \\
\text { Probability }\end{array}$ & $\geq 0.05$ \\
\hline RMSEA & $\leq 0.08$ \\
\hline GFI & $\geq 0.90$ \\
\hline AGFI & $\geq 0.90$ \\
\hline ource: Ghozali (2011) &
\end{tabular}

Table 2. Scale Rate for Suitability Program in AHP*

\begin{tabular}{cl}
$\begin{array}{c}\text { Scale } \\
\text { Rate }\end{array}$ & \multicolumn{1}{c}{ Description } \\
& $\begin{array}{l}\text { Criterion/alternative A is as } \\
\text { important as B }\end{array}$ \\
1 & A is slightly more important \\
3 & than B \\
5 & A is more important than B \\
7 & A is far more important than B \\
9 & A is absolutely more important \\
$2,4,6,8$ & than B \\
& In case of hesitation arises \\
between two criteria
\end{tabular}

\section{Results and Discuss}

\section{The Residents' Education and Life Norms}

The Island' residents have formal education, only averaged elementary school because the school building facilities for secondary schools (Junior High School and Senior High School) were not available. Moreover, the fulfillment of family needs forced every family' members to work. The most residents was elementary school graduated (138 people) with productive ages of 19-25 years old is 40 people, the group of age 26-36 years old is 35 people, and the group of age 37-47 years old is 28 people. The residents in that age groups are the household head who has a role to earn money for living, and with a minimum educational condition, they potentially exploit the resources inappropriately.

The Island residents have life norms or neighbor manners and nature that are considered as a provider of resources for life. The life norms to fellows derived from the interactions among each other (socialization) over the years by passing through hardship and pleasure as a fellow community members.

The residents' life norms toward nature derive from interactions between human and nature in lifetime from generation to generation in which human perceive that nature has provided its resources for human's life needs and human must respond by keeping it preserved.

\section{The View and Knowledge of Residents to Coastal Ecosystems}

The view of Lingayan island residents to coastal ecosystems consists of the view in the context of "interest"; the use of resources is determined and limited to broader matters such as social and moral factors meaning that exploitation is followed by the actions to conserve resources. Then, the view in the context of "value" is the view related to economic context (price) that resources can be exploited to gain economical yield and there is no obligation to conserve them since each resource has its ability to recover (Fauzi, 2004). On the other hand, the view between both of them states that the use of resources only to fulfill life needs with no obligation to conserve them. The residents with the view in the context of "interest" had the percentage which was almost the same as the ones having the view in the context of "value at $37.44 \%$ and $35.55 \%$ respectively. However, the residents with the view that the use depends on the condition of life needs were $27.01 \%$, and it will potentially increase the number of residents who use resources without any resource conservation actions.

The utilization of coastal resources in Lingayan Island depends on resident's education level. The unfriendly actions performed by the residents that have low educational level, as well as supported by negative attitudes and their livelihood needs. The usage of fish bomb, intoxication (potassium cyanide) and rock mining are their destructive actions done in Lingayan Island until recently. These actions were performed with the purpose to gain more resources, be faster, and cheaper although it has been found to have high risks that could endangered their life.

\section{The Island's Infrastructures}

Minimum infrastructures at Lingayan island is divided into 3 conditions, i.e.: (1) damaged and unused; (2) good and unused; and (3) good and used. The infrastructures development in Lingayan Island was prepared by the central and regional governments support and communities initiative. However, its' usage could not be done maximize since lack of people's awareness as well as weak government control so that the infrastructures are not maintained, and even some infrastructures were in good condition but unused (Figure 2). 

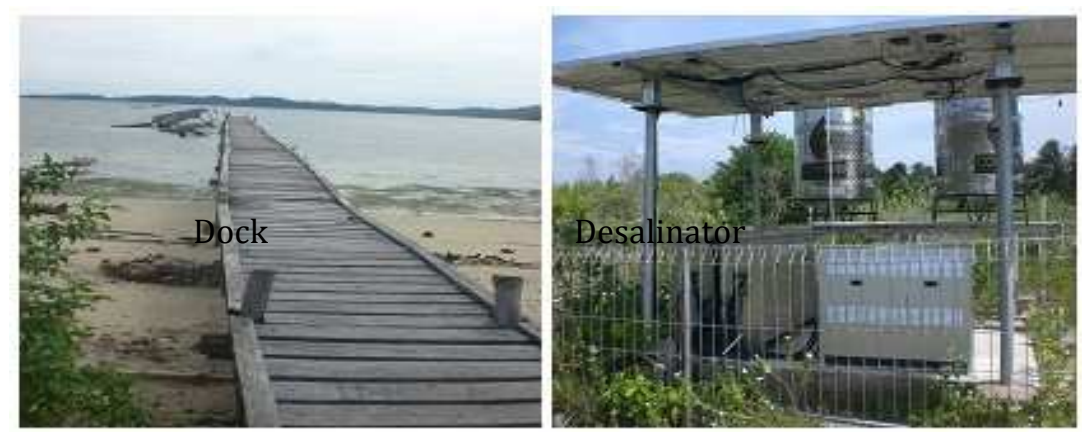

Figure 2. Infrastructures on Lingayan Island: Damage and not maintained, and good condition but unable to use because without operator.

\section{Fish Resources Accessibility}

The ability to get fish resource for fishermen in Lingayan Island are still low because the fishing facilities (canoe, motorized boat of katinting 10-15 pk, and simple fishing equipment) are not adequate so that their fishing coverage is limited in nearby area with limiting catch. Accessibility is also related to the permit for using coastal resources. Control on the resources utilization in the Lingayan waters and the North Dampal Sub-District have not be executed optimally so that it caused overlapping utilization in certain waters area between the users having adequate facilities and the users with minimum facilities. Traditional fishermen compete to catch fishes with motorized boats that have bigger capacity of fishing equipments.

\section{Capital and Diversifications of Economic Enterprises}

The venture run by Lingayan residents have low capital in average. For traditional fishing capture with only one day fishing trip only need capital between IDR 100,000 and IDR 200,000. Whereas, for dried fish processing and fresh fish selling, they needed less capital, between IDR 100,000 and IDR 200,000. The residents' average income per family are $\pm 50,000$ each day or between $1,300,000$ and $1,800,000$ per month. The venture types run by the residents are less varied and limited to traditional fishing in which the catches sold as a fresh fish, so did not provide an added value.

\section{The Design of Causality Relation Model}

The causality relation model was made based on the relation among the components (materials) in a system that the components will interact to each other in a border separated from their environment (Fitzgerald and Fitzgerald, 1987). The causal relation model was equipped by 40 construct indicators on each exogenous and endogenous variable. Then, it was analyzed to find identified model by considering its construct indicators that resulted in significant value.

The analysis results resulted in the fit model of social ecological system through the estimation of full structural equation modeling in which only construct indicators tested in confirmatory were included (Figure 3). The path diagram model of causal relationship of components met the fit criteria with chi-square of 236.994 which was not significant, GFI had the ratio of 0.884 , and AGFI had the value of 0.838 which was almost to be fit and still under the recommended value requirement. However, in this case, there were many samples so that the one to consider was the compliance of RMSEA criteria of 0.083 . The relation among the component was shown by the interaction of each component resulting in positive value. It means that every component affects each other or there was an association one each other and give values of the standardized coefficients were positive with probability $\geq$ 0.05 . While the path diagram model of causal relationship of components in socio-economical systems was obtained fit criteria recommended with chi-square 192.824 in accordance with the data observation provided, RMSEA had the value of 0.081 and GFI had the ratio of 0.900 , and indicating that the model has been fit to all variables which were related one to each other. All components had positive association and there was an association with the probability value $\geq 0.05$ (Figure 4 ).

While the path diagram model of causal relationship of components in socio-economical systems was obtained fit criteria recommended with chi-square 192.824 in accordance with the data observation provided, RMSEA had the value of 0.081 and GFI had the ratio of 0.900 , and indicating that the model has been fit to all variables which were related one to each other. All components had positive association and there was an association with the probability value $\geq 0.05$ (Figure 4 ). 


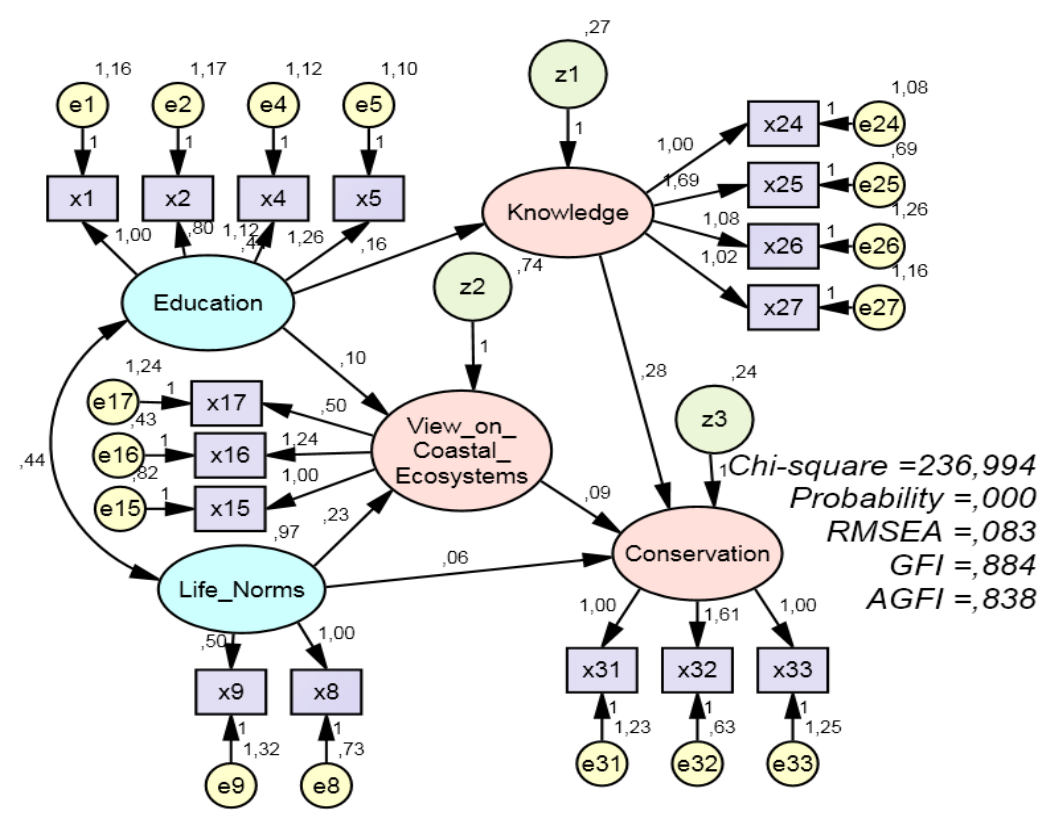

Figure 3. Fit Model of causality path diagram of socio-ecological component at the Lingayan island

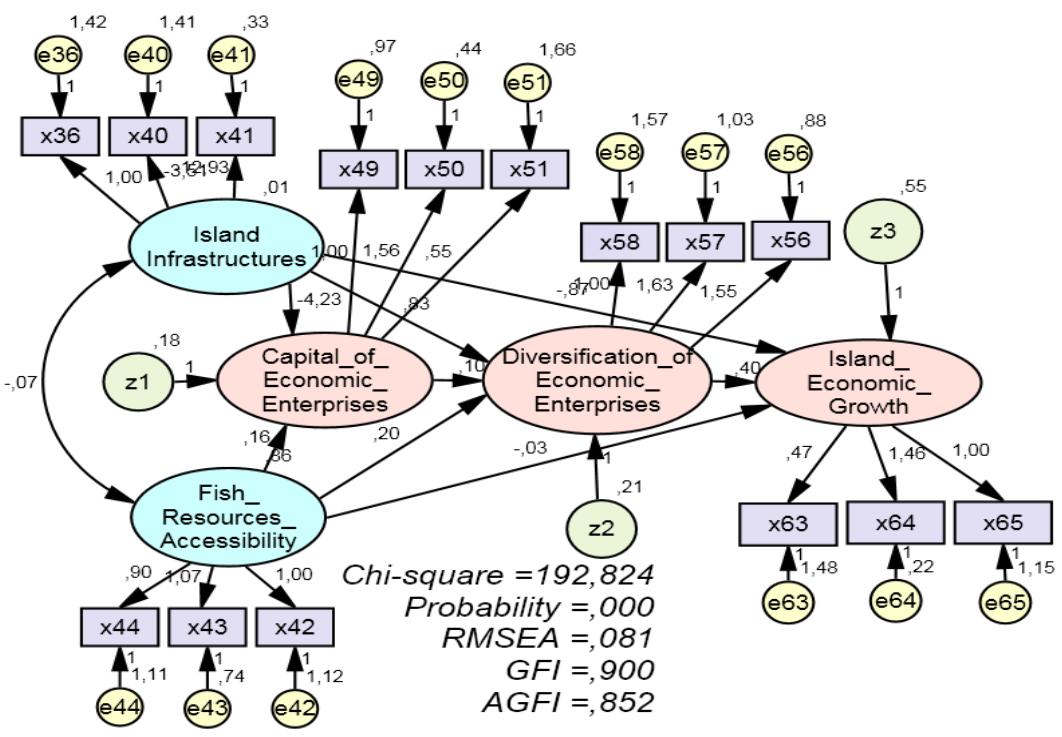

Figure 4. Fit Model of causality path diagram of socio-economical component at the Lingayan island

\section{Island Development Management}

The research recommend that the socio-ecological and socio-economical aspects be employed for island development and people empowerment in Lingayan Island, however by considering on high development cost, the implementation should be arranged in accordance to the needs' priority. Therefore, a strategy is required to facilitate tits' implementation. In order to determine the need value and the appropriate alternative activity, a hierarchical structure be designated as illustrated in the Figure 5.
The needs and wants of Lingayan residents with the approach of socio-ecological and socio-economical aspects are shown in Figure 6, in which program of capital aid has the highest weight value of 0.206 , followed by island infrastructures development 0.174 , education program 0.167 and life norms 0.113 . So far, the continuity of the residents' economic enterprise does not last longer because of no capital aid. The residents with profession of traditional fishermen could not go to the sea continuously because they ran out of money. The provided capital aid should be managed by the group of 
people for various kinds of enterprises, such as seaweed cultivation, grouper marine aquaculture and dried fish processing. The island infrastructures improvement will help to reduce economic burdens during operation of the economic enterprises, so that the capital can be minimized. Capital aid and infrastructures improvement will support the growth of economic enterprise in Lingayan Island. Education is the third program criteria required to educate people of Lingayan Island. The education is targeted to the understanding on the importance of coastal and marine ecosystems adjusted with condition and characteristics of the island.

The appropriate activity to support the island's economic growth is seaweed cultivation that can be done by considering resident's characteristic and island's water condition that protected from the waves. Whereas, the sustainable activity to support conservation effort is restoration with government monitoring and community empowerment (Figure 7).

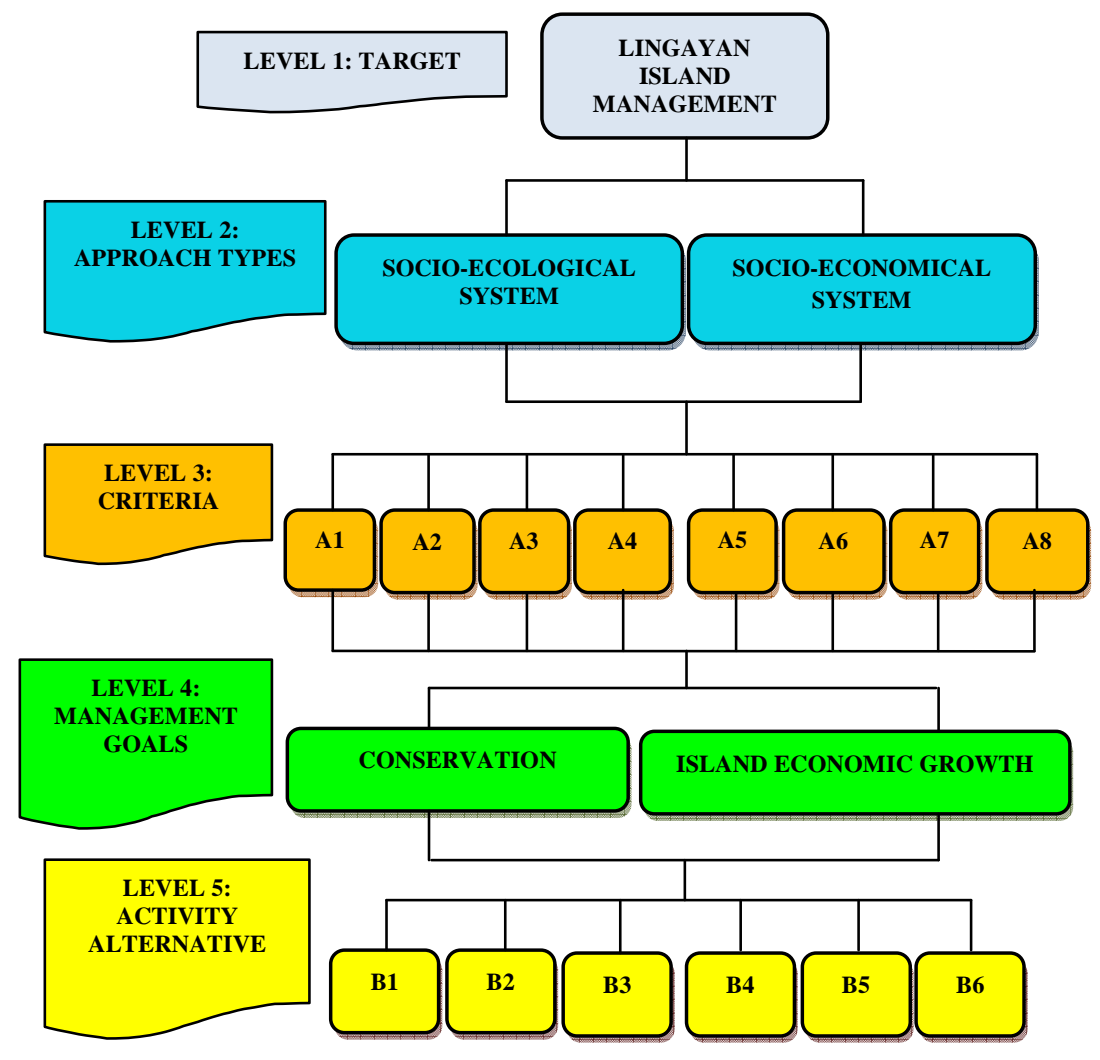

Symbols: A1=Education; A2 =Life Norms; A3=Knowledge; A4=View on Coastal Ecosystems; A5=Island Infrastructures; A6=Capital; A7=Fish Resources Accessibility; A8=Diversification of Economic Enterprises; B1= Rehabilitation; B2=Restoration; B3=Remediation; B4=Dried Fish Processing; B5=Seaweed Cultivation; B6=Grouper Marine Aquaculture.

Figure 5. Hierarchical structure in determining need value and the alternative of appropriate activities for management strategy of Lingayan island.

\section{Capital \\ Island Inf rastructures \\ Education \\ Life Norms \\ Diversification of Economic \\ View on Coastal Ecosystems \\ Fish Resources Accessibility \\ Knowledge \\ Inconsistency $=0,07$ \\ with 0 missing judgments.}

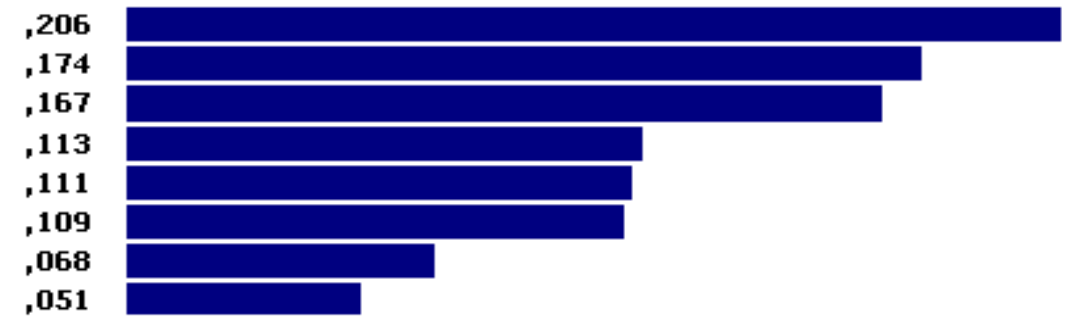

Figure 6. Need value of Lingayan's resident to program criteria based on socio-ecological and socio-economical systems.

The socio-ecological and socio-economical components in the system has been analyzed and then be determined the priority programs for management stages. The management stages are prepared in the table of priority action program as shown in Table 3 .

The management purposes that are conservation of coastal ecosystems and the island economic growth be a 
limiting parameter on what to be achieved from the whole management stages. The related aspects on socioecological and socio-economical system are be input as special indicator for improvement goal of designed programs. Then, in the table be found development possibilities as the management stages.

The responses in table column contain the consideration of nature and character which are the nature of the residents and also contain the suggestions that strengthen a development possibility to be stronger to implement. The potency of an island is also described as the information supporting a development step to perform. Then, the consideration was taken in priority for management stage by seeing the comparative value analyzed and the order of program action priorities that will be executed during management stages.

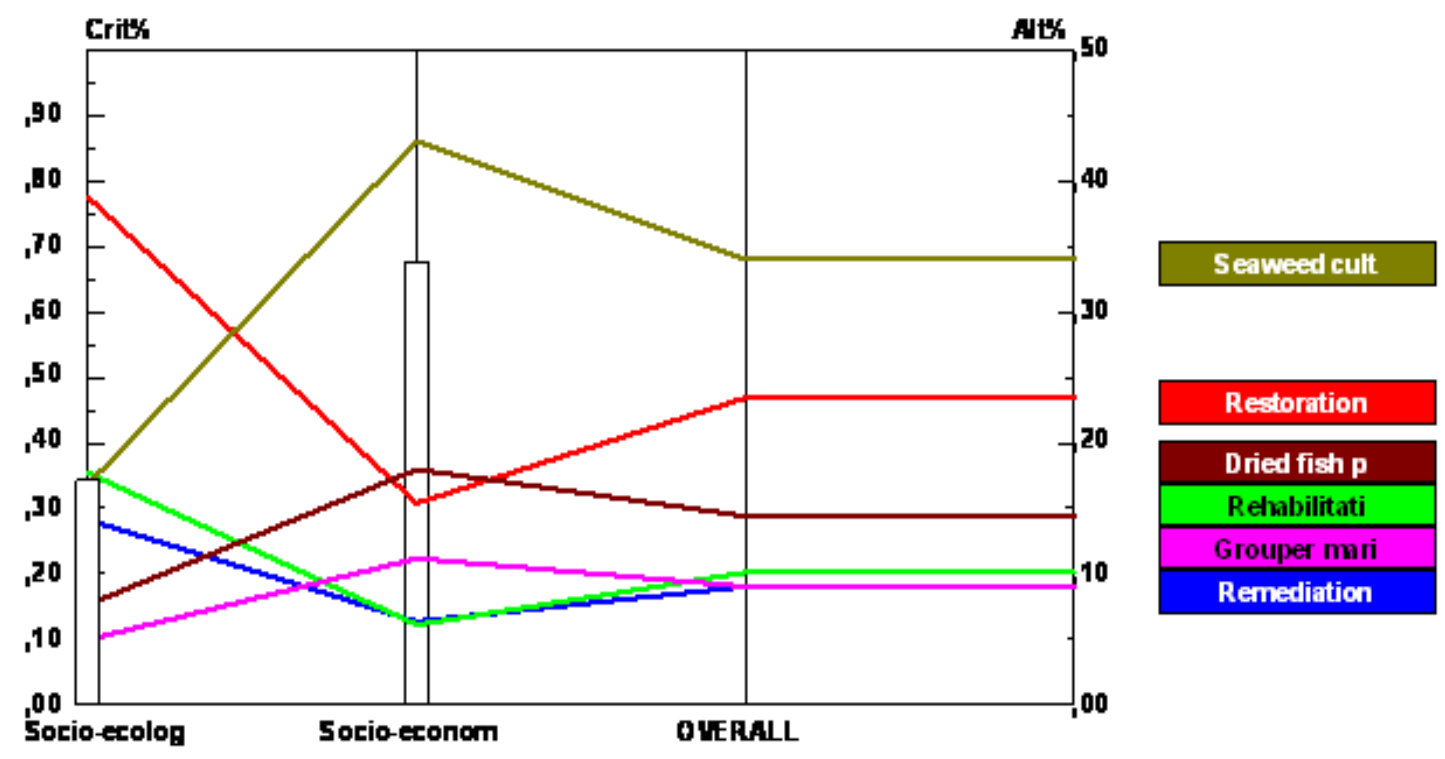

Figure 7. Alternative Suitability Activities to support Island's Economic Growth and Coastal Ecosystems Conservation Program in Lingayan Island.

This study provided the information on the strategic roles and problems of Lingayan Island as the determination for the area of Indonesian water territory. It can be the major discussion material, particularly on how to design a management strategy for Lingayan Island with the approaches in accordance with the characteristics of the island and the residents.

Socio-ecological system is a human social systems in which their elements interact to natural elements in an integrated manner and a reversible relationship (Carpenter et al., 1999). According to Folke (2006), a socio-ecological system was built from the existence relationship between human and nature and can be used to understand the whole concept of integration between human and their nature. Moreover, integrating local perceptions can enhance socialecological resilience (Badrango, 2007). Based on those opinions, Lingayan Island must be resolved by conservation efforts through the involvement of people awareness. Public awareness was encouraged through formal education program, establishing existing life norms, improving their views and knowledge on the benefits of coastal resources. People's economic growth and continuity can be triggered by improving infrastructures, strengthening accessibility to get fish resource, providing capital and building economic enterprise variety. The objectives of Lingayan island management are to establish strategic roles by conserving coastal ecosystems and the island economic growth.

Socio-ecological system is a human social systems in which their elements interact to natural elements in an integrated manner and a reversible relationship (Carpenter et al., 1999). According to Folke (2006), a socio-ecological system was built from the existence relationship between human and nature and can be used to understand the whole concept of integration between human and their nature. Moreover, integrating local perceptions can enhance social-ecological resilience (Badrango, 2007). Based on those opinions, Lingayan Island must be resolved by conservation efforts through the involvement of people awareness. Public awareness was encouraged through formal education program, establishing existing life norms, improving their views and knowledge on the benefits of coastal resources. People's economic growth and continuity can be triggered by improving infrastructures, strengthening accessibility to get fish resource, providing capital and building economic enterprise variety. The objectives of Lingayan island management are to establish strategic roles by conserving coastal ecosystems and the island economic growth. 
Table 3. Priority Action Program in Lingayan Island*

\begin{tabular}{|c|c|c|c|c|c|}
\hline $\begin{array}{l}\text { Need Value of } \\
\text { Resident's } \\
\text { Lingayan } \\
\end{array}$ & $\begin{array}{c}\text { Management } \\
\text { Goal }\end{array}$ & $\begin{array}{l}\text { Alternative } \\
\text { Suitability } \\
\text { Activities } \\
\end{array}$ & Expansion Possible & $\begin{array}{c}\text { Comparison } \\
\text { Value }\end{array}$ & $\begin{array}{l}\text { Priority } \\
\text { Action } \\
\text { Program }\end{array}$ \\
\hline $\begin{array}{l}\text { Capital of } \\
\text { Enterprises }\end{array}$ & \multirow{2}{*}{$\begin{array}{l}\text { Island } \\
\text { Economic } \\
\text { Growth }\end{array}$} & \multirow[b]{2}{*}{$\begin{array}{l}\text { Seaweed } \\
\text { Cultivation }\end{array}$} & $\begin{array}{l}\text { Implementation to capital aid } \\
\text { and training appropriate for } \\
\text { residents }\end{array}$ & 0,206 & 1 \\
\hline $\begin{array}{l}\text { Island } \\
\text { Infrastructures }\end{array}$ & & & $\begin{array}{l}\text { Infrastructures development, } \\
\text { such as a dock, a fish auction } \\
\text { place and electric installation } \\
\text { development }\end{array}$ & 0,174 & 2 \\
\hline Education & \multirow{2}{*}{ Conservation } & \multirow{2}{*}{$\begin{array}{l}\text { Restoration of } \\
\text { Coastal } \\
\text { Ecosystems }\end{array}$} & $\begin{array}{l}\text { Implementation to } 12^{\text {th }} \text { years } \\
\text { education program }\end{array}$ & 0,167 & 3 \\
\hline Life Norms & & & $\begin{array}{l}\text { Training and development } \\
\text { (culture and religion) }\end{array}$ & 0,113 & 4 \\
\hline $\begin{array}{l}\text { Diversification } \\
\text { of Economic } \\
\text { Enterprises }\end{array}$ & $\begin{array}{l}\text { Island } \\
\text { Economic } \\
\text { Growth }\end{array}$ & $\begin{array}{l}\text { Seaweed } \\
\text { Cultivation }\end{array}$ & $\begin{array}{l}\text { Implementation to enterprises } \\
\text { diversification training and skill } \\
\text { programs }\end{array}$ & 0,111 & 5 \\
\hline $\begin{array}{l}\text { View on } \\
\text { Coastal } \\
\text { Ecosystems }\end{array}$ & Conservation & $\begin{array}{l}\text { Restoration of } \\
\text { Coastal } \\
\text { Ecosystems }\end{array}$ & $\begin{array}{l}\text { Working training to } \\
\text { ecosystems } \text { coastal } \\
\text { necessary existence } \\
\text { programs }\end{array}$ & 0,109 & 6 \\
\hline $\begin{array}{l}\text { Fish Resources } \\
\text { Accessibility }\end{array}$ & $\begin{array}{l}\text { Island } \\
\text { Economic } \\
\text { Growth }\end{array}$ & $\begin{array}{l}\text { Seaweed } \\
\text { Cultivation }\end{array}$ & $\begin{array}{l}\text { Improvement government and } \\
\text { residents control to coastal } \\
\text { ecosystems utilization } \\
\text { programs; Design to coastal } \\
\text { planning document, } \\
\text { improvement catching } \\
\text { equipment programs. }\end{array}$ & 0,068 & 7 \\
\hline Knowledge & Conservation & $\begin{array}{l}\text { Restoration of } \\
\text { Coastal } \\
\text { Ecosystems } \\
\end{array}$ & $\begin{array}{l}\text { Socialization action about } \\
\text { useful ecosystems and habitat } \\
\text { restoration }\end{array}$ & 0,051 & 8 \\
\hline
\end{tabular}

* Source: Research Output, 2014.

\section{Conclusion}

Programs on Improving resident' education, building life norms, and improving views and knowledge on the benefits of coastal resources are related to each other and can affect the conservation effort of coastal resources in Lingayan Island. The island infrastructure development and improvement of resource accessibility has positive effect to increasing capital and business variety, and simultaneously influenced the growth of residents' economic enterprise in Lingayan. The main programs are capital support and island infrastructures development as well as education improvement and life norms development.

\section{References}

(1) Badrango, F.D. (2007). Integrating Local Perceptions for Enhancing Sosial-Ecological Resilience: The Case of Small Scale Fishery in the Chwaka Bay of Zanzibar. Master's Thesis. Stockholm University.

(2) Carpenter, S., Brock, W., and Hanson, P. (1999). Ecological and Social Dynamics in Simple Models of Ecosystem Management Ecology and society. University of Wisconsin. Madison. USA. Conservation Ecology Journal 3(2): 4-10; http:// www.consecol.org/vol3/iss2/art4/

(3) Crona, B. (2006). Of Mangroves and Middlemen, A study of social and ecological linkages in a coastal community. Summary of Doctoral Thesis, Stockholm University.

(4) Damsar (2002). Sociology Economic. Revision Ed. Rajawali Press. Jakarta. ISBN: 9791486786, pp: 18.

(5) Fauzi, A., (2004). Economic of Natural and Environmental Resources. Theory and Applications. 1st Ed. PT. Gramedia Pustaka Utama. Jakarta. ISBN: 9792210423, pp: 259.
(6) Ghozali, I., (2011). Equation Structural Model, Application Concept with Program Amos 19.0. $4^{\text {th }}$ Ed. Publisher Biro of Diponegoro University. Semarang. ISBN: 9797042332, pp: 363.

(7) Fitzgerald, J.M. and A.F. Fitzgerald, (1987). Fundamental of System Analysis: Using Structured Analysis and Design Techniques. $3^{\text {th }}$ Ed. John Wiley \& Sons. New York. ISBN-13: 9780471885979, pp: 928.

(8) Folke, C., Hahn, T., Olsson, P., and Norberg, J., (2005). Adaptive Governance of Sosial-Ecological Systems. Annual Reviews. Environment Resource. (30) : 441-73; doi: 10.1146/annurev.energy.30.050504.144511.

(9) Folke, (2006). Resilience: The Emergence Of A Perspective For Sosial-Ecological Systems Analyses. International Journal. Global Environmental Change 16 (2006): 253-267; http://www.resalliance.org/file.php?id=6324\&name $=1212585387$ 6 resilience the emergence of a perspective.pdf.

(10) Halliday, A., and Glaser, M., (2011). A Management Perspective on Social Ecological Systems: A generic system model and its application to a case study from Peru. Society for Human Ecology. Human Ecology Review 18 (1): 1 - 18 http://www.humanecologyreview. org/pastissues/her181/halliday.pdf.

(11) Peloquin, C. (2007). Variability, Change and Continuity in SocialEcological Systems: Insight from James Bay Cree Cultural Ecology. Master's Thesis. Faculty of Graduate Studies of the University of Manitoba.

(12) Saaty, T.L. (1990). How to Make a Decision: The Analytic Hierarchy Process. European Journal of Operational Research (48): 9-26; $\quad$ http://www.sbuf.se/ProjectArea/Documents/ ProjectDocuments/06F167EF-B243-48ED8C45F7466B3136EB\%5CwebPublishings\%5 Chow\%20to\%20make\% 20decision\% 20AHP.pdf.

(13) Scheffer, M., Brock, W., and Westley, F. (2000). Socioeconomic Mechanisms Preventing Optimum Use of Ecosystem Services: An Interdisciplinary Theoretical Analysis. Socioeconomics and Ecosystem Services Journal (3) : 451-471. https://sustainability. 
International Journal of Science and Engineering, Vol. 7(1)2014:52-60, Mohammad Saleh Lubis et al.

water.ca.gov/documents/18/3334093/Socioeconomic + Mechanisms +Preventing+Optimum+Use + of + Ecosystem + Services.pdf

(14) Seixas, C.S. (2002). Social-Ecological Dynamics in Management Systems: Investigating a Coastal Lagoon Fishery in Southern Brazil. Dissertation. Natural Resources Institute. University of Manitoba.
(15) United Nations, (1982). United Nations Convention on the Law of the Sea-UNCLOS. The Regime of Islands. http://www.un.org/depts/los/convention_agreements/texts/unclos LUNCLOS-TOC.htm. (Accesed on April 13, 2011). 